\title{
Silurian Bivalvia from Chichagof Island, Southeast Alaska (Alexander terrane)
}

\author{
JIŘí Ǩ̌́lŽ, ROBERT B. BLODGETT \& DAVID M. ROHR
}

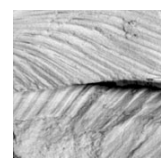

\begin{abstract}
The new Silurian Bivalvia Goniophora thula-Mytilarca boucoti Community from a new locality east of the Hoonah Airport on Chichagof Island, Southeast Alaska, U.S.A. is composed of 9 species [?Colpomya aff. hugini Liljedahl, 1994 and ?Colpomya aff. audae Liljedahl, 1994 (Colpomyidae); Modiolopsis aff. modiolaris Conrad, 1838 (Modiolopsidae); Mytilarca boucoti sp. nov. (Ambonychiidae); ?Schizodus sp. A and ?Schizodus sp. B (Schizodidae); Sanguinolites sp. (Sanguinolitidae); ?Modiomorpha sp. and Goniophora thula sp. nov. (Modiomorphinae)]. In this paper two new species are described. The Goniophora thula-Mytilarca boucoti Community most probably occupied a gently inclined upper slope environment lying seaward of a cyanobacterial reef front which marked the outer edge of a late Silurian carbonate platform (represented by the Kennel Creek Limestone). The fauna of this locality consists of a rich benthos, especially rich in brachiopods, but secondarily dominated by bivalves and gastropods. Cephalopods are rare, favositid tabulate corals are also present, but form only a very minor component. The new community is most closely related to the homologous and analogous late Wenlock Bivalvia community described from Gotland, Sweden, Baltica. Similar biotic ties are with the shallow water early Ludlow Janicula potens Community from the Prague Basin, Bohemia, Perunica. Cosmopolitanism is characteristic for the Silurian Bivalvia genera, which were dispersed in most regions of the world due to their relatively long pelagic larval life and relatively small distances between the basins, islands and continents in the $\mathrm{Si}$ lurian. For the distribution of Bivalvia during the Silurian were more limiting physical factors like temperature, salinity, substrate, food, oxygen content, light, and depth. The fauna described here is from the Alexander terrane, an accreted terrane which appears to represent a rifted block of the eastern Siberian palaeocontinent. The latter interpretation is based on faunal affinities, notably brachiopods, but suggested by other groups such as gastropods and sponges, as well as on the basis of similarities in sedimentary succession. - Key words: Bivalvia, Silurian, late Wenlock to early Ludlow, new taxa, Alexander terrane, Southeast Alaska, U.S.A., palaeoecology, slope facies, palaeogeography, Perunica, Baltica.
\end{abstract}

KŘ́ǐž, J., BLODGETT, R.B. \& RoHR, D.M. 2011. Silurian Bivalvia from Chichagof Island, Southeast Alaska (Alexander terrane). Bulletin of Geosciences 86(2), 241-258 (5 figures, 1 table). Czech Geological Survey, Prague. ISSN 1214-1119. Manuscript received March 25, 2011; accepted in revised form April 27, 2011; published online May 24, 2011; issued June 20, 2011.

Jiři Kř̌̌ž, Czech Geological Survey, Klárov 3, P.O. Box 85, CZ-118 21, Praha 1, Czech Republic; jiri.kriz@geology.cz. - Robert B. Blodgett, Consulting Geologist, 2821 Kingfisher Drive, Anchorage, Alaska 99502, U.S.A.; robertbblodgett@yahoo.com • David M. Rohr, Department of Earth and Physical Sciences, Sul Ross State University, Alpine, Texas 79832, U.S.A.; drohr@sulross.edu

The present paper describes a new Bivalvia community discovered and collected by R.B. Blodgett, D.M. Rohr, and J. Skaflestad on July 30, 2010 in the north side of a small quarry about $1 \mathrm{~km}$ east of Hoonah Airport runway on Chichagof Island, Southeast Alaska, U.S.A. (locality 10RB10 Latitude $58^{\circ} .05 .716^{\prime} \mathrm{N}$., Longitude $\left.135^{\circ} .23 .152^{\prime} \mathrm{W}\right)$. The quarry (Fig. 1) is reached by a small short road leading from the west from Forest Service Road 8052, the main road leaving and heading south of the town of Hoonah. The quarry is situated in the NW1/4 of the SE1/4 of section 35, T. 43 S., R. 62 E., Juneau A-5 1 : 63,360 scale quadrangle (Map edition 1994). The quarry exposes two separate stratigraphic intervals: a lower greenish-grey, medium-bedded siltstone interval which forms the base of the quarry, and an upper limestone interval which forms cliffs on the south and west side of the quarry. The fossil-rich part (field locality 10RB10) of the siltstone beds is exposed on the north side of quarry (near NE end of quarry). The siltstone beds near the fossil locality strike N-S and dip $70-75^{\circ}$ to the West. A rich fauna of brachiopods along with a lesser amount of gastropods accompanies the bivalve community. The fossiliferous zone which yielded this fauna was the only easily visible fossil-rich part of the siltstone beds exposed in the quarry. The described specimens JK 17 853-JK 17984 are deposited in the collection of Early Palaeozoic bivalves in the Czech Geological Survey, Prague, Bohemia. 

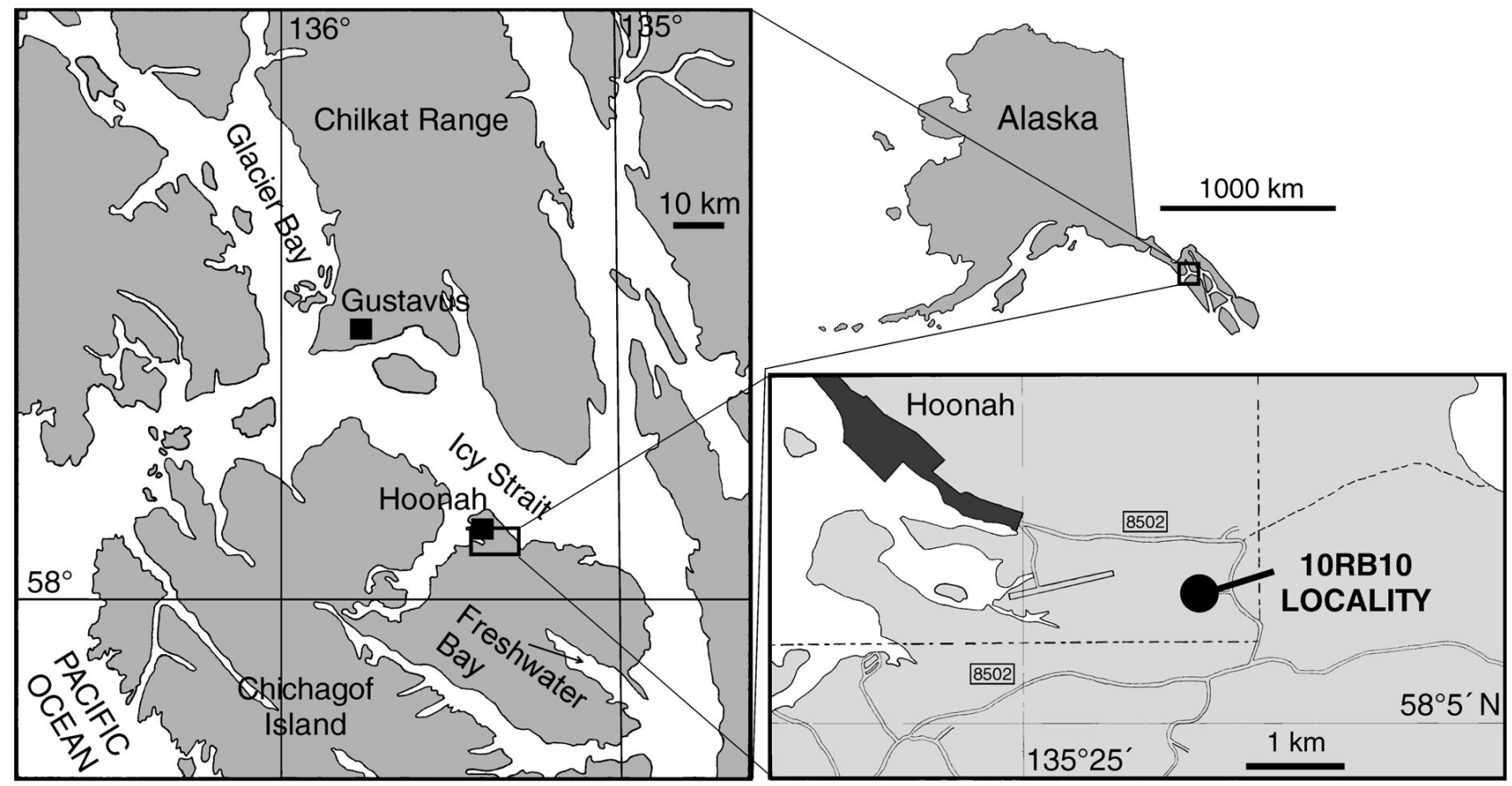

Figure 1. Location of the field locality 10RB10, East of Hoonah Airport, Latitude $58^{\circ} 05.716^{\prime}$ N., Longitude $135^{\circ} 23.152^{\prime}$ W, Chichagof Island, Southeast Alaska, U.S.A.

\section{Geological setting}

(by Robert B. Blodgett \& David M. Rohr)

Palaeozoic age rocks are exposed throughout much of northeast Chichagof Island, Southeast Alaska. However, very little study has been made of the Palaeozoic fauna and flora from this island. The only formally described and illustrated fossil is the upper Silurian Pycinodesma benjamini (Kirk), described by Kirk (1927a) under his newly established genus name Pycnodesma, which he later changed (Kirk 1927b) to Pycinodesma upon learning that the genus name was pre-occupied. This particular species was found in exposures of the type section of the Kennel Creek Limestone on the southern side of Freshwater Bay, about $40 \mathrm{~km}$ south-east of Hoonah. Cardiola aff. agna Kříž, 1979, the characteristic representative of Nepiomorphia Kř́̌ž, 2007 was found by Bruce Reed in the early Gorstian of Alaska at Jones River (Kříž 1979, pp. 14 and 72). Blodgett and Rohr visited the small town of Hoonah, situated in the northeast part of Chichagof Island, in late July, 2010 with the purpose of conducting a short reconnaissance field study of the Silurian-Devonian strata exposed on this part of the island.

Geologic maps covering all or parts of Chichagof Island include Lathram et al. (1958), Lathram et al. (1959), Loney et al. (1963a), Loney et al. (1963b) and Karl (1999). Much of the basic stratigraphic nomenclature for this part of the island was established in the paper of Loney et al. (1963b). On the geologic map of northeast Chichagof Is- land of Karl (1999), the area including the quarry from which this collection was made was shown as being part of the Devonian age Cedar Cove Formation. Karl (1999, Table 1, map No. 3) provided some information on conodonts from the limestones which are exposed in the upper part of this quarry. According to Anita G. Harris, who identified the fauna, it included Panderodus sp., Ozarkodina remscheidensis eosteinhornensis (Walliser), which according to her indicated a middle late Silurian-earliest Devonian (late Ludlow-early Lochkovian) age. Our field study indicated that many of the rocks exposed in the immediate area of Hoonah do not belong to the Cedar Cove Formation as indicated on the map of Karl (1999), but rather belong to a new unnamed mixed siliciclastic/limestone lithostratigraphic unit bearing late Silurian age fauna, probably forming a shelf to basin transitional lithofacies which lay to the north of late Silurian carbonate platform rocks of the Kennel Creek Limestone (Rohr et al. 2011). The Kennel Creek Limestone was established by Loney et al. (1963b), who considered it to be Middle Devonian in age. The only significant fossils found in the latter unit are the bivalve Pycinodesma and amphiporoid stromatoporoids. More recent studies in Southeast Alaska clearly indicate that Pycinodesma is late Silurian in age, as originally indicated by Kirk (1927a, b), and the Kennel Creek is now recognized to be late Silurian in age.

Carbonate platform facies of the Kennel Creek Limestone, as mentioned above, are well exposed to the south of Hoonah, most notably in and around Freshwater Bay. One 
of the nearest Kennel Creek quarry exposures to our bivalve locality contained cyanobacterial reefal mound buildups, similar to those found in coeval platform edge rocks exposed throughout much of the Alexander terrane of Southeast Alaska and the Farewell terrane of southwest Alaska (Clough \& Blodgett 1988, Rigby et al. 1994), as well as in the Urals. The bivalve fauna described here is the only diverse collection of bivalves known from the late Silurian of Chichagof Island. As mentioned above, numerous specimens of the genus Pycinodesma have been noted from the late Silurian age Kennel Creek Limestone, and one species, $P$. benjamini was formally established by Kirk (1927a) based on collection from the south side of Freshwater Bay.

The Palaeozoic strata of northeast Chichagof Island are part of the Alexander terrane, part of the accretionary complex of allochthonous terranes which characterizes much of Southeast Alaska, northwestern British Columbia, and southwestern Yukon Territory (Fig. 2). This terrane was among the first such terranes to be recognized in western North America (Berg et al. 1972, Jones et al. 1972). Recent palaeobiogeographic studies indicate that the Alexander terrane is faunally most similar to Siberia (Blodgett et al. 2002, 2003; Pedder 2006), notably its eastern portion. It is now considered that this terrane most likely originated as a rifted block of the eastern Siberian palaeocontinent, probably breaking away in the latter part of the Devonian (Blodgett et al. 2010).

\section{Systematic palaeontology}

(by Jiří Kříž)

Abbreviations. - V - valve, $\mathrm{L}$ - length of the shell, $\mathrm{H}$ - height of the shell, W - width of the shell, W/2 - width of one valve (Křriž 1969); JK - collection of the Lower Palaeozoic bivalves deposited in the Czech Geological Survey, Prague. All measurements are in millimetres.

Class Bivalvia Linné, 1758

Superfamily Colpomyoidea Pojeta \& Gilbert-Tomlinson, 1977

Family Colpomyidae Pojeta \& Gilbert-Tomlinson, 1977

\section{Genus Colpomya Ulrich, 1893}

Type species. - Colpomya constricta Ulrich, 1893, U.S.A., Kentucky, Middle Ordovician.

Remarks. - The Alaskan bivalves classified as ?Colpomya Ulrich, 1893 have shell form strongly similar to that of Colpomya. The hinge is unknown (not preserved) so they are referred to this genus with a question mark.

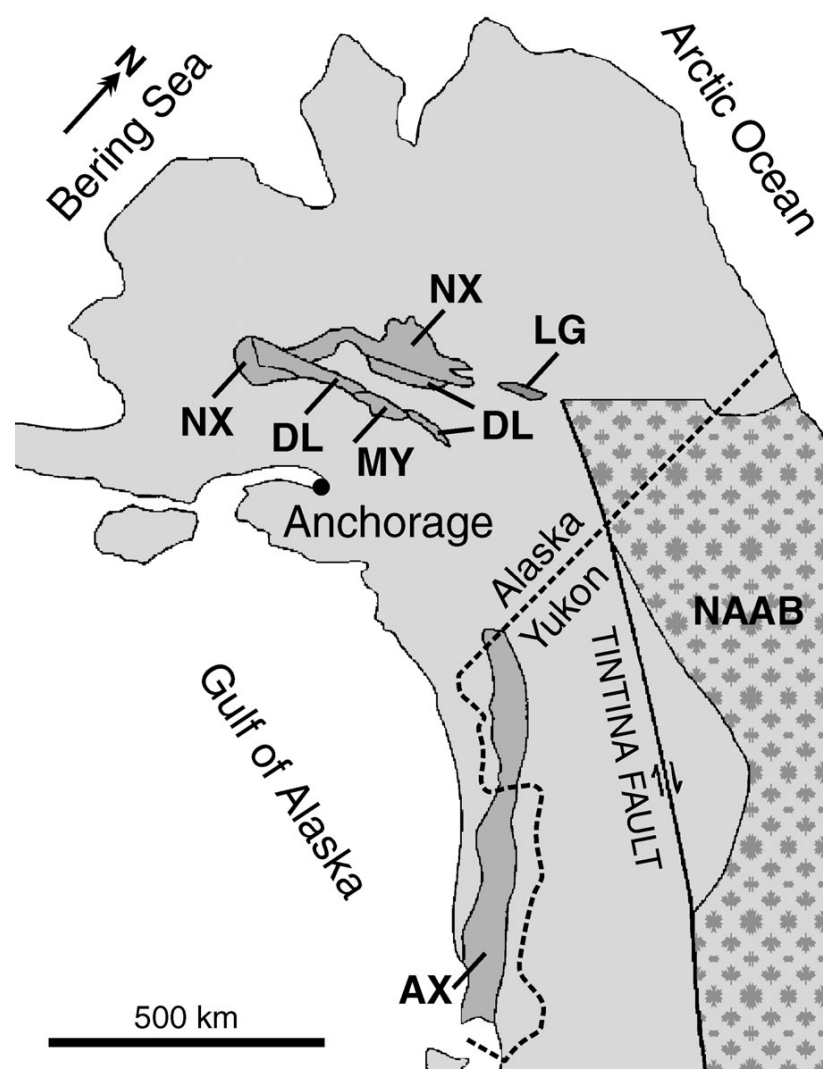

Figure 2. Tectonostratigraphic terranes and component subterranes in Alaska. AX - Alexander terrane; LG - Livengood terrane, Subterranes of the Farewell terrane: DL - Dillinger; MY - Mystic; NX - Nixon Fork. NAAB - North American autochtonous basement (after Blodgett et al. 2010).

\section{?Colpomya aff. hugini Liljedahl, 1994}

Figure 4D

Material. - Three specimens: internal mould of right valve with fragment of recrystallized shell wall in the umbonal part (JK 17 979), internal mould of right valve with fragment of recrystallized shell wall in the umbonal part (JK 17 973), and internal mould of right valve (JK 17 980).

Description. - Small valve (length maximally $8.8 \mathrm{~mm}$, height maximally $7.4 \mathrm{~mm}$ and width/2 maximally $2.8 \mathrm{~mm}$ ) is obliquely subovate, inequilateral, and moderately inflated. Umbo prominent, beak small, prosogyrate, slightly above the dorsal margin, almost not raised above the commissure plain, at two fifths of the shell length from anterior. Dorsal margin long, more than one half of shell length, and slightly convex. Anterior part lobate, relatively narrow and rounded. Almost straight ventral margin is relatively long. Posterior part of the shell is much larger than anterior part and posterior margin is rounded. Maximum height of the shell is reached approximately at 1/3 the shell length from anterior. Shell surface is smooth, with a few irregular low 
growth bands developed. Ligament is most probably opisthodetic. Shell thickness is $0.11 \mathrm{~mm}$. Other features unknown.

\begin{tabular}{|c|c|c|c|c|}
\hline \multicolumn{5}{|c|}{ Dimensions. - } \\
\hline Specimen & V & $\mathrm{L}$ & $\mathrm{H}$ & $\mathrm{L} / \mathrm{H}$ \\
\hline JK 17980 & $\mathrm{R}$ & $>6.6$ & 4.8 & 1.4 \\
\hline JK 17973 & $\mathrm{R}$ & 8.3 & 6.6 & 2.8 \\
\hline JK 17979 & $\mathrm{R}$ & 8.8 & 7.4 & 2.6 \\
\hline
\end{tabular}

Discussion. - The specimen is most closely related to Colpomya hugini Liljedahl, 1994 from the Homerian, Wenlock, Mulde Beds of Djupvik, Gotland, Sweden by general size, shape and surface sculpture represented by only very few irregular wide growth bands. Especially characteristic is the extended anterior part and a very high posterior part of the valve.

\section{?Colpomya aff. audae Liljedahl, 1994}

Figure 4H, J, K

Material. - Three specimens: internal mould of right valve (JK 17 964), deformed internal mould of right valve (JK 17 965), and counterpart of right valve with outer surface sculpture (JK 17 969).

Description. - Small valve (length maximally $16.6 \mathrm{~mm}$, height maximally $11.0 \mathrm{~mm}$ and width/2 maximally $3.1 \mathrm{~mm}$ ) is obliquely elongated, inequilateral, and moderately inflated. Umbo prominent, blunt, prosogyrate, slightly above the dorsal margin, and in less than one fourth of the shell length from anterior. Umbonal ridge well developed between umbo and posterior extremity. Dorsal margin is long, more than four fifths of the shell length, and slightly convex. Anterior part lobate, relatively narrow and rounded. Ventral margin is long, slightly convex. Posterior part of the shell is larger than anterior part and posterior extremity rounded to subangular. Maximum height of the shell is reached in the posterior part. Irregularly spaced low growth bands and furrows form the shell surface. Ligament is probably opisthodetic. Other features unknown.

\section{Dimensions. -}

$\begin{array}{llrrr}\text { Specimen } & \text { V } & \text { L } & \text { H } & \text { L/H } \\ \text { JK 17 964 } & \text { R } & 12.9 & 7.1 & 3.0 \\ \text { JK 17 965 } & \text { R } & 16.6 & 11.0 & 3.1\end{array}$

Discussion. - The specimens are most closely related to ?Colpomya audae Liljedahl, 1994 from the Ludlow, Burgsvik Beds, Gotland, Sweden by general shape and surface sculpture. Characteristic is especially the extended anterior part and subangular rounded posterior part of the valve. As already mentioned by Liljedahl (1994, p. 62) the features of
?Colpomya audae are very similar to the early Gorstian, Ludlow Modiolopsis concors Barrande, 1881 from Praha-Butovice, Prague Basin, Bohemia. The ?Colpomya aff. audae from southeast Alaska is also similar to the late Ludlow specimen of Modiolopsis concors Barrande (1881, pl. 262, figs III/1-3) from Praha-Lochkov, Prague Basin Bohemia, which differs by having regularly spaced narrow growth bands and furrows.

Superfamily Modiolopsoidea P. Fischer, 1886

Family Modiolopsidae P. Fischer, 1886

\section{Genus Modiolopsis Hall, 1847}

Type species. - Pterinea modiolaris Conrad, 1838, U.S.A., New York, Pulaski Formation, Ordovician.

\section{Modiolopsis aff. modiolaris (Conrad, 1838) \\ Figure 4I}

Material. - Slightly compressed internal mould of right shell, JK 17966.

Description. - Valve medium in size ( $\mathrm{L}=17.2 \mathrm{~mm}, \mathrm{H}=$ $11.1 \mathrm{~mm}, \mathrm{~W} / 2=>1.9$ ), elongated, slightly diagonally modioliform, inequilateral, inflated; maximum width in about $1 / 2$ of the shell length from anterior. Anterior part lobate, evenly rounded, posterior part of the shell is distinctly larger than anterior part. Maximum height is reached approximately at slightly more than three quarters of the shell length from anterior. Umbo is prominent, above the hinge line, at $1 / 4$ of the shell length from anterior, and prosogyrate. Dorsal margin is long, about $1 / 2$ of shell length, straight. Ventral margin is long, slightly convex. Posterior margin evenly rounded. Surface sculpture composed of irregularly spaced narrow growth bands and furrows. Ligament is probably amphidetic or opisthodetic. Hinge probably edentulous, large anterior adductor muscle scar is developed on the anterior part, close to umbo. Other features unknown.

Discussion. - According to Křǐž \& Steinová (2009) more than 163 Ordovician species were classified in the past under Modiolopsis Hall, 1847 (Pojeta 1971). The number of the Silurian and Devonian species was not counted, but is also very high. The specific classification is very difficult when only a general modioliform shape and surface sculpture are known. For that reason the specimen from Alaska is compared with the Ordovician type species Modiolopsis modiolaris (Conrad, 1838), which differs generally in its larger shells. On the specimen figured by Pojeta (1971, pl. 15, figs 1-3) the posterior myophoric buttress is partly preserved and the impression of anterior adductor muscle scar is also developed. Modiolopsis antiquior Bar- 
rande, 1881, from the Late Ordovician, Sandbian, Letná Formation, sandstones, Děd Hill near Beroun, the Prague Basin is also very similar, differing from the Alaska specimen by its more robust and larger shells.

Superfamily Ambonychioidea S.A. Miller, 1877 Family Ambonychiidae S.A. Miller, 1877

\section{Genus Mytilarca Hall \& Whitfield, 1869}

Type species. - Inoceramus chemungensis Conrad, 1842, U.S.A., New York, Late Devonian, Chemung Stage.

Mytilarca boucoti sp. nov.

Figure 3A-Q

Holotype. - Internal mould of the right valve with posterior laterals and anterior cardinals preserved, JK 17 942, figured on Fig. 3D-F.

Paratypes. - JK 17 939-JK 17 941, JK 17 943-JK 17 950, JK 17 953-JK 17 955, measured for dimensions, included into assemblage analysis and figured on Fig. 3A-C, G-Q.

Derivation of name. - In honour of Arthur J. Boucot, Professor of Zoology and Geology, Oregon State University, Corvallis, Oregon, U.S.A., good friend, expert in the Silurian and Devonian brachiopods and stratigraphy, biogeography and palaeoecology of the Silurian and Devonian rocks of the World.

Type locality. - U.S.A., Southeast Alaska, Chichagof Island, small quarry SE of Hoonah, field locality 10RB10, Latitude $58^{\circ} 05.716^{\prime} \mathrm{N}$., Longitude $135^{\circ} 23.152^{\prime} \mathrm{W}$.

Type horizon. - Late Wenlock or early Ludlow, mediumbedded lower siltstone interval below an overlying, upper limestone interval.

Material. - 13 left, 11 right valves, and 2 fragments.

Diagnosis. - Silurian Mytilarca with postero-ventrally elongated, ovate shells, and with hinge composed of two or three slightly elongated anterior cardinal teeth and two posterior lateral teeth.

Description. - Shell medium size (length maximally $14.3 \mathrm{~mm}$, height maximally $11.1 \mathrm{~mm}$ and width $/ 2$ maximally $5.3 \mathrm{~mm}$ ), postero-ventrally elongated, ovate, equivalved, inequilateral, and obese, lacking the anterior lobe. Umbos are prominent, in extreme terminal position, beaks prosogyrate. Outer surface sculpture consists of growth wrinkles and of irregular flat narrow growth bands and fur- rows. Byssal sinus and byssal gape not developed. Ligament external, low ligament area with numerous duplivincular grooves and ridges. Hinge in the left valve composed of two or three slightly elongated cardinal teeth anteriorly of umbo, posterior one longer. In the posterior part of the shell, close to the hinge line two narrow lateral teeth are developed, lower one usually longer. Shell thickness is $0.34 \mathrm{~mm}$. Other features unknown.

Dimensions. - (Specimens are slightly deformed.)

$\begin{array}{llrrr}\text { Specimen } & \mathrm{V} & \mathrm{L} & \mathrm{H} & \mathrm{W} / 2 \\ \text { JK 17 944 } & \mathrm{L} & 4.8 & 4.4 & 1.5 \\ \text { JK 17 950 } & \mathrm{R} & 10.4 & 10.7 & 4.1 \\ \text { JK 17 940 } & \mathrm{R} & 11.0 & 10.3 & 5.3 \\ \text { JK 17 949 } & \mathrm{L} & 12.3 & 12.8 & 3.3 \\ \text { JK 17 942 } & \mathrm{R} & 14.3 & 11.1 & 4.6\end{array}$

Discussion. - Mytilarca boucoti sp. nov. differs from all the species described by Isberg (1934) from the Late Ordovician of Sweden by ovate, postero-ventrally elongated shells and by blunt large umbo. M. mareki Kříž \& Steinová, 2009 from the latest Ordovician of the Prague Basin Bohemia is most closely related to $M$. boucoti sp. nov. but it is broadly ovate, more ventrally elongated and more obese, it has mostly one or two, even three lateral teeth developed. The Silurian and Devonian species of Mytilarca described by Barrande (1881) from the Prague Basin of Bohemia differ in having dorso-ventrally elongated shells and by mostly pointed narrow umbos. M. amii McLearn, 1924 from the late Přídolí of Arisaig, Nova Scotia differs by its mytiliform outline, slightly concave anterior margin and pointed umbo. Mytilarca acutirostra (Hall, 1867) described by Watkins (1997) from the Wenlock Racine Formation of Wisconsin and Illinois, North America is larger and differs by its more postero-ventrally elongated shells. The other species of $M y$ tilarca described by Hall (1884) from the Late Devonian of North America differ also by dorsoventrally elongated shells with pointed and mostly slender umbos.

Mode of life. - Semi-infaunal, byssate.

Occurrence. - Type locality.

Superfamily Trigonioidea Lamarck, 1819

Family Schizodidae Newell \& Boyd, 1975

\section{Genus Schizodus Verneuil \& Murchison, 1844}

Type species. - Axinus obscurus Sowerby, 1821, England, Lancashire, late Permian.

Remarks. - In the collection of Alaskan bivalves are several relatively small single valves with a shell form similar 
to that of the Early Palaeozoic bivalves assigned by several authors to the Schizodidae. Schizodus? sp. from the early Ludlow, Wales, Great Britain (Newell \& Boyd 1975), the Gedinnian Schizodus aff. cuneus Hall, 1883, and the Emsian Schizodus aff. appressus (Conrad, 1842) from Guangxi, China (Pojeta et al. 1986), Silurozodus gotlandicus Liljedahl, 1992 from the late Wenlock and Ludlow, Gotland, Sweden, Schizodus sp. nov. (Watkins 1997) from the late Wenlock Racine Formation of Wisconsin and Illinois, North America, and Janicula potens (Barrande, 1881) from the late Wenlock and early Ludlow, Prague Basin, Bohemia (Kříž 2008). At present this group of the possible Silurian and Devonian trigoniaceans is not well understood, and specimens are difficult to classify (Pojeta et al. 1986, p. 79). The hinge of the Alaskan specimens is unknown (not developed or not preserved) so they should be referred to this genus only with a question mark.

\section{?Schizodus sp. A}

Figure 4E, F

Material. - Five specimens: three internal moulds of right valve (JK 17 984, JK 17 983, JK 17 977), and two counterparts of left valve with outer surface sculpture preserved (JK 17 976, JK 17 975).

Description. - Small shell (length maximally $6.9 \mathrm{~mm}$, height maximally $>5.8 \mathrm{~mm}$ and width $/ 2$ maximally $1.5 \mathrm{~mm}$ ), quadrangular-subovate, inequilateral, postero-ventrally elongated, and inflated. Umbos prominent, prosogyrate, raised above the dorsal margin, situated in the anterior $1 / 3$ of the shell length. Umbonal ridge well developed, it does not reach the postero-ventral extremity. Antero-dorsal and anterior margins evenly rounded and continuing in the convex ventral margin terminating in the rounded obtuse postero-ventral angle. Posterior margin obliquely truncated, postero-dorsal angle rounded. Dorsal margin is convex. Outer shell surface is formed by growth wrinkles and by a few less prominent irregular narrow growth bands or furrows. Inner shell surface is smooth with a few less prominent irregular narrow growth bands or furrows. Other features unknown.

\begin{tabular}{lrrrr}
\multicolumn{2}{l}{ Dimensions. - } & & & \\
Specimen & V & L & H & W/2 \\
JK 17 977 & R & 5.8 & 3.5 & 1.5 \\
JK 17 983 & R & 6.1 & 4.2 & $>1.4$ \\
JK 17 984 & R & 6.9 & $>5.8$ & $>1.3$
\end{tabular}

Discussion. - The Alaskan ?Schizodus sp. A is very similar in general shape to the specimens from the Devonian, Gedinnian, Guangxi, China compared by Pojeta et al. (1986, p. 80, pl. 23, figs 1, 2) with Schizodus cuneus Hall (1883, pl. 75 , figs 29,$30 ; 1885$, pl. 75 , figs 29,30 ).

\section{?Schizodus sp. B}

Figure 4A-C

Material. - Three specimens: internal mould of left valve with fragment of recrystallized shell wall in the umbonal part (JK 17 978), internal mould of right valve (JK 17 982), and counterpart of left valve with outer surface sculpture preserved (JK 17 981).

Description. - Small shell (length maximally $8.1 \mathrm{~mm}$, height maximally $5.8 \mathrm{~mm}$ and width/2 maximally $2.4 \mathrm{~mm}$ ), quadrangular-subovate, inequilateral, and moderately inflated. Umbos prominent, prosogyrate, slightly raised above the dorsal margin, situated in the anterior 1/4 of the shell length. The umbonal ridge does not reach posterior margin. Anterior margin is evenly rounded and continuing in the convex ventral margin and terminating in the rounded posterior. Dorsal margin is convex. Outer shell surface is formed by growth wrinkles with very few irregularly spaced flat growth bands. Inner shell surface is smooth. Other features unknown.

\begin{tabular}{|c|c|c|c|c|}
\hline $\begin{array}{l}\text { Dimensions } \\
\text { specimen }\end{array}$ & V & $\mathrm{L}$ & $\mathrm{H}$ & $\mathrm{W} / 2$ \\
\hline JK 17982 & $\mathrm{R}$ & $>4.5$ & 3.9 & 1.0 \\
\hline K 17978 & $\mathrm{~L}$ & $>8.1$ & 5.8 & 2.4 \\
\hline
\end{tabular}

Figure 3. A-Q-Mytilarca boucoti sp. nov. • A, B - right valve, internal mould, JK 17 940, paratype; A - lateral view, $\times 3.8$; B - dorso-lateral view, detail of posterior lateral teeth and the counterpart of ligamental area, $\times 5.9$. $\bullet$ C - left valve, internal mould, JK 17944 , paratype, lateral view, $\times 10.4$. - D-F - right valve, internal mould, JK 17 942, holotype; D - dorso-lateral view, detail of cardinal teeth, $\times 14.5$; E - lateral view, $\times 3.3$; F - dorso-lateral view, $\times 4.8 \cdot \bullet \mathrm{G}, \mathrm{H}-$ left valve, internal mould, JK 17 946, paratype; G - lateral view, $\times 4.3$; H - dorso-lateral view, detail of posterior lateral teeth, $\times 6.4$. - I-J - left valve, internal mould with fragment of the recrystallized shell, JK 17945 , paratype; I - lateral view, $\times 4$; J - dorso-lateral view, detail of posterior lateral teeth and the counterpart of ligamental area, $\times 5.5$. $\bullet \mathrm{K}-$ right valve, internal mould, JK 17950 , paratype, lateral view, $\times 3.9 . \bullet \mathrm{L}, \mathrm{M}-$ left valve, internal mould, JK 17 949, paratype; L - dorso-lateral view, detail of posterior lateral teeth and the counterpart of ligamental area, $\times 6.3$; M - lateral view, $\times$ 3.3. $\bullet \mathrm{N}-$ left valve, internal mould, JK 17 939, paratype, dorso-lateral view, detail of posterior lateral teeth and the counterpart of ligamental area, $\times 10.5 . \bullet$ O - right valve, internal mould, JK 17 948, paratype, dorso-lateral view, detail of cardinal teeth and the counterpart of ligamental area, $\times 14.7$. - P - right valve, external mould, JK 17 953, paratype with fragment of recrystallized shell, lateral view, detail of outer and inner surface sculptures, $\times 5.6$. - Q - left valve, external mould, JK 17 955, paratype, lateral view, detail of outer surface sculture, $\times 14$. 


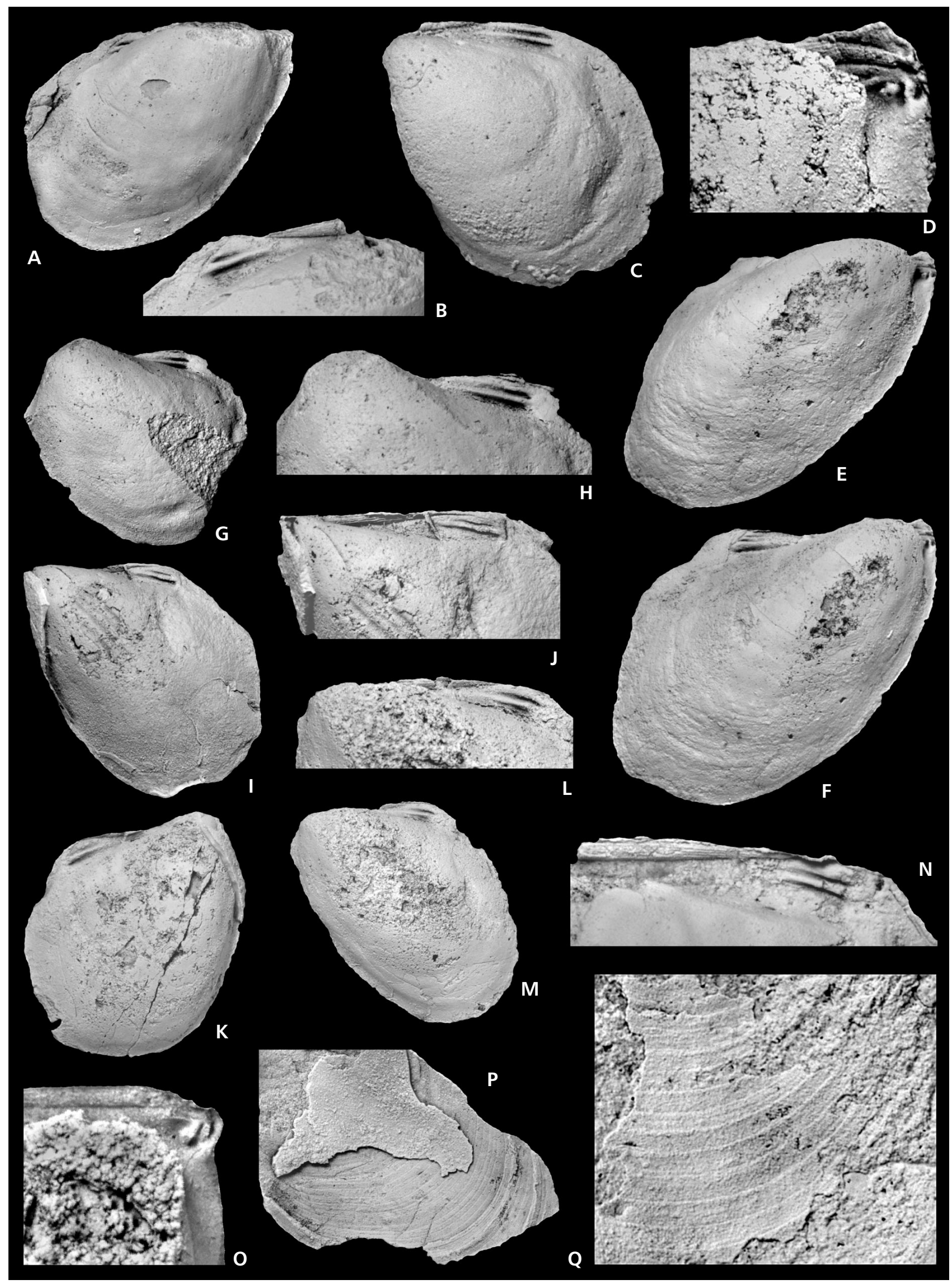


Discussion. - In general ?Schizodus sp. B has a similar general shape to Schizodus oblatus Hall (1883, pl. 75, fig. 43; 1885, pl. 75, fig. 43) from the Devonian, Chemung Group. Also very similar is Schizodus sp. nov. figured by Watkins (1997) from the Wenlock Racine Formation of Wisconsin and Illinois, North America which is larger but shows generally an identical morphology.

Superfamily Grammysioidea S.A. Miller, 1877

Family Sanguinolitidae S.A. Miller, 1877

\section{Sanguinolites McCoy, 1844}

Type species. - Sanguinolites discors McCoy, 1844, Ireland, Early Carboniferous.

\section{Sanguinolites sp.}

Figure 4G, M-O

Material. - Seven fragments (JK 17 956, JK 17 958-JK 17 962, and JK 17 968).

Description. - Shell transverselly subovate, inequilateral, elongated, and obese. Umbos are prominent, in almost anterior position, prosogyrate. Umbonal ridge is indistinct, rounded, and becomes obsolete before reaching posterior extremity. Dorsal margin is long, slightly convex. Anterior part is lobate. Ventral margin is long, straight. Posterior margin of adult shell is rounded. Surface sculpture is composed of the growth wrinkles and prominent convex wide growth bands and relatively narrow furrows. Growth bands increase in number posteriorly of anterior part by intercalation or bifurcation. Other features unknown.

Remarks. - A characteristic feature of Sanguinolites are prominent convex growth bands increasing in number posteriorly of the anterior part by intercalation or bifurcation well demonstrated on Sanguinolites nagaolingensis Pojeta et al., 1986 from the earliest Devonian, Guangxi, China (p. 87, pl. 31, figs 5, 6). The same feature was described in Sanguinolites? drupa Kříž, 2008 from the early Ludlow of the Prague Basin, Bohemia (p. 272, fig. 12B-G). This fea- ture is well exhibited in the Alaskan specimen JK 17 968, figured as Fig. 4M. Other mentioned fragments have similar size and sculpture. The juvenile specimen JK 17962 is figured as Fig. 4G.

Superfamily Modiomorphoidea S.A. Miller, 1877 Subfamily Modiomorphinae S.A. Miller, 1877

\section{Genus Modiomorpha Hall \& Whitfield, 1869}

Type species. - Pterinea concentrica Conrad, 1838, U.S.A., New York, Middle Devonian.

\section{?Modiomorpha sp.}

Figure 4L

Material. - Counterpart of right valve anterior (length $20 \mathrm{~mm}$ ) with preserved outer surface sculpture (JK 17 957).

Description. - Shell probably modioliform, inequilateral, moderately inflated. Anterior part is lobate. Outer surface sculpture consists of fine growth bands and furrows. Growth bands decrease in number posteriorly and became irregularly spaced and wider. Other features unknown.

Remarks. - This fragment of the relatively largest shell in the Alaskan Bivalvia community shows a decreasing number of growth bands posteriorly (an opposite situation exists in Sanguinolites McCoy, 1844), and is similar to that of the modiomorphid anterior part of the shell. It may be related to Modiolopsis Hall, 1847 or to Modiomorpha Hall \& Whitfield, 1869.

\section{Genus Goniophora Phillips, 1848}

Type species. - Cypricardia cymbaeformis Sowerby in Murchison, 1839, England, upper Ludlow.

\section{Goniophora thula sp. nov.}

Figure 5A-R

Holotype. - Right valve, internal mould, JK 17 875, figured on Fig. 5M-O.

Figure 4. A-C-?Schizodus sp. B. A - counterpart of the left valve showing outer surface sculpture, JK 17981 , lateral view, $\times 9.7$. B - left valve, internal mould, JK 17 978, lateral view, $\times 4.5$; C - right valve, internal mould, JK 17 982, lateral view, $\times 2.7$. $・$ D - ?Colpomya aff. hugini Liljedahl, 1994 , right valve, internal mould, JK 17 979, lateral view, $\times 3.6$. $\bullet$ E, F - ?Schizodus sp. A. E - right valve, internal mould, JK 17 984, lateral view, $\times 6.6$; F - right valve, internal mould, JK 17 983, lateral view, × 7. • G, M-O - Sanguinolites sp. G - right valve, internal mould, JK 17 962, lateral view, × 3.9; M - fragment of the right valve, internal mould, JK 17 968, lateral view, $\times 3.3 ; \mathrm{N}$ - fragment of the right valve, anterior part, internal mould, JK 17 958, lateral view, $\times 4.3$; O - fragment of the left valve, posterior part, internal mould, JK 17 959, lateral view, × 3.3. • H, J, K - ?Colpomya aff. audae Liljedahl, 1994 . $\mathrm{H}$ - right valve, internal mould, JK 17 964, lateral view, $\times 4.6$; J - deformed right valve, internal mould, JK 17965 , lateral view, $\times 6.6$; K - counterpart of the right valve, outer surface sculpture, JK 17 969, lateral view, $\times 5.1$. $・$ I - Modiolopsis aff. modiolaris Conrad, 1838 , right valve, internal mould, JK 17 966, lateral view, $\times 5.8$. $\bullet$ L - ?Modiomorpha sp., counterpart, fragment of the right valve, anterior part, JK 17957 , lateral view, $\times 2.5$. 


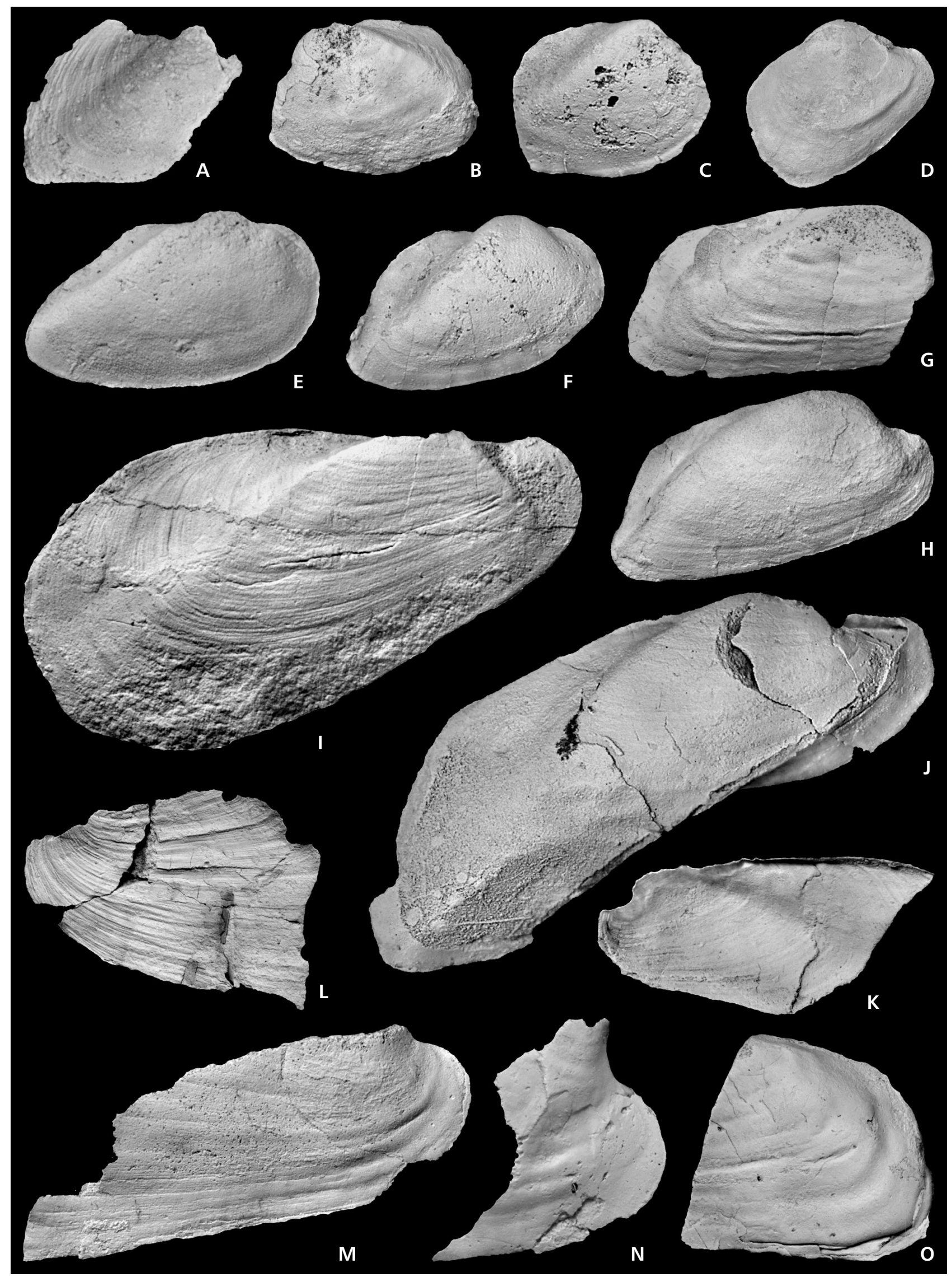


Paratypes. - JK 17 863, JK 17 867, JK 17 869, JK 17 873, JK 17 874, JK 17876 - JK 17 887, measured for dimensions and figured on Fig. 5A-L, P-R.

Derivation of name. - From Latin Thule (Greek Thoule), feminine, farthest north.

Type locality. - U.S.A., Southeast Alaska, Chichagof Island, small quarry SE of Hoonah, 10RB10, Latitude $58^{\circ} 05.716^{`}$ N., Longitude $135^{\circ} 23.152^{`} \mathrm{~W}$.

Type horizon. - Late Wenlock or early Ludlow, mediumbedded lower siltstone interval below an overlying upper limestone interval.

Material. - 1 shell with conjoined valves, 11 left, 12 right valves, and 69 fragments.

Diagnosis. - A Silurian Goniophora with strongly inequilateral, postero-ventrally elongated, lanceolate shells, with outer surface sculpture composed of numerous, irregularly spaced narrow growth bands and furrows and with dorsal (posterior) and ventral (anterior) parts separated by prominent S-shaped carina between the umbo and extended ventral extremity. Posterior slope is overhanging.

Description. - Shell medium size (length maximally $15.7 \mathrm{~mm}$, height maximally $14.5 \mathrm{~mm}$ and width/2 maximally $5.3 \mathrm{~mm}$ ), lanceolate, equivalve, strongly inequilateral, more postero-ventrally elongated, and inflated. No byssal gape. Umbos prominent, in anterior third of the dorsal margin line, closely incurved, beaks prosogyrate. Each valve subdivided into dorsal (posterior) and ventral (anterior) parts by sinuous, prominent high carina with a rounded crest between umbo and postero-ventral extremity. The carina is composed of interior transversal segments described by Křǐž (2008). Each segment has a wide base, which sits on the very thin inner layer of the shell. Laterally the width of the segments decreases, near the rounded top of the carina it increases. When only the inner surface of the shell is preserved, in the place of carina only a flat ridge with growth bands corresponding to the carina interior segments is preserved. Frequently, only the ventral part of the carina interior is preserved. Hinge line relatively short, slightly curved. Anterior margin is lobate, ventral margin long, a little concave. Ventral extremity of the carina is claw like, ventrally extended and anteriorly curved. Posterior margin long, convex, posterior slope of valve is overhanging. Outer surface sculpture consists of numerous growth wrinkles and irregularly spaced narrow, rounded growth bands and furrows. Inner surface sculpture consists also of numerous flat narrow growth bands and furrows. Hinge not well preserved. On the internal mould of the left valve (paratype JK 17 874) one cardinal and possibly two relatively small sockets are preserved anteriorly below the umbo. Posterior reinforcement ridge well developed close to the hinge line, slightly curved. Anterior reinforcement between the anterior adductor muscle scar impression and umbo is short. Anterior adductor muscle scar subcircular and deeply impressed on the inner side of the anterior lobe. Shell wall is $0.24-0.31 \mathrm{~mm}$ thick.

Dimensions. - (Specimens are slightly deformed.)

$\begin{array}{lllr}\text { Specimen } & \text { L } & \text { H } & \text { W/2 } \\ \text { JK 17 877 } & 10.0 & 13.2 & 4.1 \\ \text { JK 17 876 } & 12.6 & 13.2 & 4.2 \\ \text { JK 17 875 } & 15.7 & 14.5 & 5.3\end{array}$

Discussion. - Goniophora thula sp. nov. is closely related to Goniophora ascia Křriž, 2008 from the early Gorstian (Ludlow) of the Prague Basin, Bohemia in having a similarly developed carina and general shape of the shell, but differs from the Bohemian species by its smaller shell, overhanging posterior slope, more posteriorly than ventrally elongated shell, by the presence of irregularly spaced narrow wrinkles and growth bands and furrows, and by a more extended ventral extremity of its carina. Goniophora onyx Liljedahl, 1984 from the late Homerian of Gotland has a slightly larger shell, posterior slope overhanging and a ventral extremity of the carina that is also claw like,

Figure 5. A-R-Goniophora thula sp. nov. • A - deformed shell with conjoined valves, internal mould, JK 17873 , paratype, postero-dorsal view, $\times 2.3$. - B - left valve, internal mould, JK 17 874, paratype, latero-dorsal view, detail of the posterior and anterior reinforcement ridges and anterior adductor muscle scar, $\times 4.3$. $\bullet$ C - right valve, external mould of outer surface, JK 17863 , paratype, lateral view, $\times 3.5$. $\bullet$ D - left valve, external mould of outer surface of antero-ventral part, JK 17883 , paratype, antero-ventral view, $\times 4.5$. $\bullet$ E - right valve, external mould of outer surface, JK 17884 , paratype, lateral view, $\times 3.7 . \cdot \mathrm{F}-$ left valve, internal mould with fragment of recrystallized shell, JK 17887 , paratype, latero-dorsal view, detail of the posterior and anterior reinforcement ridges and anterior adductor muscle scar, $\times 7 . \bullet \mathrm{G}-$ left valve, internal mould, JK 17877 , paratype, latero-dorsal view, detail of the posterior and anterior reinforcement ridges and anterior adductor muscle scar, $\times 3.4$. $\bullet \mathrm{H}-\mathrm{I}-$ right valve, internal mould of antero-ventral part, JK 17879 , paratype; $\mathrm{H}$ - ventro-lateral view, detail of ventral extremity of carina, $\times 4.8 ; \mathrm{I}-$ ventro-lateral view, $\times 3.9$. $\bullet \mathrm{J}, \mathrm{K}-$ right valve, internal and external mould of antero-ventral part, JK 17 881, paratype; J - ventro-lateral view of internal mould, $\times 4.2 ; \mathrm{K}$ - ventro-lateral view of external mould with outer surface sculpture, $\times 4.1 . \bullet \mathrm{L}-$ right valve, internal mould, JK 17878 , paratype, ventro-lateral view showing well preserved anterior adductor muscle scar, $\times 2.3$. $\cdot \mathrm{M}-\mathrm{O}$ - right valve, internal mould, JK 17 875, holotype; $\mathrm{M}$ - dorsal view, $\times 4.5 ; \mathrm{N}-$ lateral view, $\times 4.0$; O - ventro-lateral view, $\times 3.0$. $\bullet \mathrm{P}-\mathrm{R}-$ left valve, internal mould, JK 17 876, paratype; $\mathrm{P}$ - postero-lateral view with posterior reinforcement ridge, $\times 3.1$; Q - ventro-lateral view, $\times 3.9$; $\mathrm{R}-$ lateral view, $\times 4.5$. 
Jiř́ Křriž et al. • Silurian Bivalvia from Chichagof Island, Southeast Alaska (Alexander terrane)

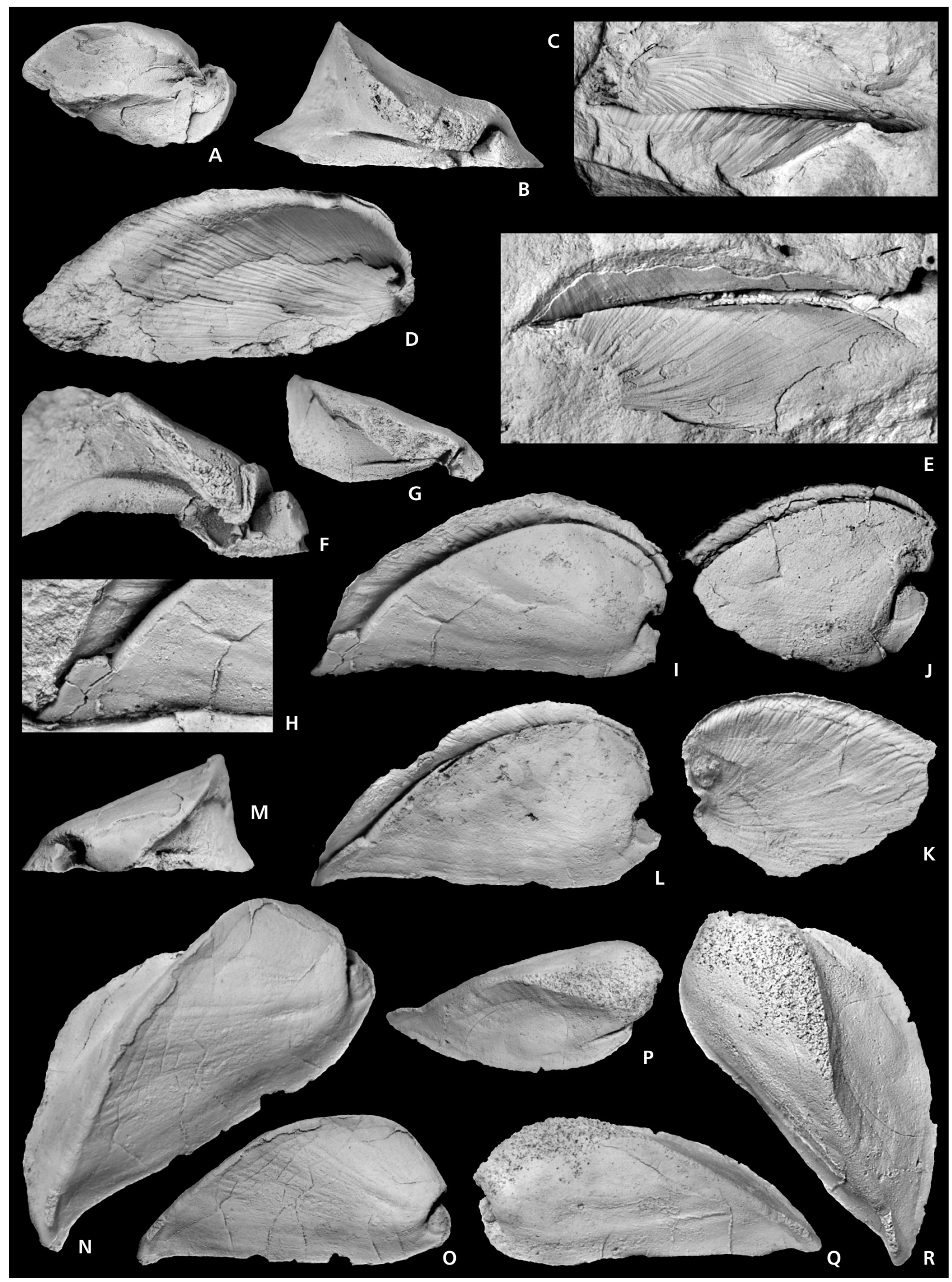


slightly curved anteriorly, but differs from Goniophora thula sp. nov. by its regular narrow growth bands and furrows. Goniophora cymbaeformis (Sowerby in Murchison, 1839) from the Ludlow of Ludlow, the Welsh Borderland, described also by Sinicyna (1964) from the Skala Formation, late Přídolí of Podolia, Ukraina, is also related to Goniophora thula sp. nov., but has a slightly larger shell and additionally differs by its more posteriorly elongated shell, and by regularly spaced narrow growth bands and furrows. Also closely related is Goniophora australis Chapman, 1908 from the Silurian of Victoria, Australia, with a similar size and sculpture, with a similar distinct carina and its anteriorly curved ventral extremity. Goniophora consimilis Billings, 1874 in McLearn, 1924 from the Stonehouse Formation, late Př́dolí of Arisaig, Nova Scotia shows a similar outer surface sculpture and well developed carina but it differs from Goniophora thula sp. nov. by its generally longer shell, by a posterior extremity of the carina that is not claw-like, and by a more lobate, concave anterior margin.

Mode of life. - Most probably byssate, semi-infaunal with the carina parallel to the sediment surface and anterior lobe dipping into the substrate (Liljedahl 1994).

Occurrence. - Type locality.

\section{Community analysis}

The Bivalvia dominated communities from Perunica and peri-Gondwana Silurian and Early Devonian carbonates were classified by Kř́̌ž (1999a) into the natural community groups, each containing homologous and analogous communities (Boucot \& Kříž 1999). These community groups are related to the slightly deeper cephalopod limestone biofacies and nearby even deeper contemporary micritic limestone biofacies. Havlíček \& Štorch $(1990,1999)$ described from the Prague Basin of Bohemia shallow water Coral-Crinoid Community Group (Kř́žz 2008) interpreted as a biostrome characterized by prevalence of crinoids, corals, stromatoporoids accompanied especially by brachiopods, bivalves, gastropods, cephalopods and trilobites. The early Ludlow Janicula potens Community (Kř́̌̌z 2008) from the Prague Basin, Bohemia is assigned to the Coral-Crinoid Community Group and represents the most diversified Bivalvia community in Bohemia (32 bivalve species). The community is contemporaneous with the Cardiola gibbosa Community (Kříž 1999a) described from the early Ludlow cephalopod limestone biofacies, Prague Basin Bohemia and other peri-Gondwanan regions and characterized by the dominant occurrence of nepiomorphian bivalves $(90.6 \%)$ including dominant species (Kř́iž 1999a, 2007). In the shallow water Janicula potens
Community the nepiomorphian bivalves represent only $0.8 \%$ in relative abundance (Kříž 2008).

The Janicula potens Community also has close biotic ties with the shallow-water analogous and homologous Bivalvia community with dominant Amphicoelia leidyi Hall, 1867 from the late Wenlock Racine Formation, Michigan Basin, North America (Watkins 1997). In the Racine Formation community also occurs the nepiomorphian Cardiola aff. gibbosa Barrande, 1881 but represents only $0.06 \%$ of relative abundance. The occurrence of nepiomorphian bivalves in such a distant basin is evidence of pelagic larval transport by surface currents without a geographic barrier between Perunica or peri-Gondwana and the cratonal interior of Laurentia.

\section{Goniophora thula-Mytilarca boucoti Community}

Name. - Used here for the first time.

Composition. - The relatively low diversity Bivalvia community is formed by 9 species: Goniophora thula, Mytilarca boucoti, Sanguinolites sp., ?Schizodus sp. A, ?Colpomya aff. audae, ?Colpomya aff. hugini, ?Schizodus sp. B, Modiolopsis aff. modiolaris, and ?Modiomorpha sp. The bivalves are accompanied by abundant brachiopods, which are by far the most abundant element of the fauna and include Isorthis (Arcualla) sp., Mesoleptostrophia sp., Silurian-type Howellella sp., new family and genus of strophic atrypacean, Morinorhynchus sp., coarsely costate "Atrypa", several specimens of a gypidulinid, a single specimen of Cyrtia sp. and a single specimen of an athyroid. The brachiopod fauna is of particular note in lacking any specimens of large pentameroid genera such as Kirkidium, Brooksina, Cymbidium, or Harpidium which are so typical of the shallow-water carbonate facies of the Heceta Limestone (also within the Alexander terrane) to the south on Prince of Wales and western neighbouring islands (Kirk \& Amsden 1952; Blodgett et al. 2002, 2010). Gastropods are less common (approximately equal in number of total specimens with that of the bivalves) and include Loxonema sp. (a small species), Medfracaulus sp. and Bathmopterus sp. and a single specimen of Trochonema? sp. Only seven specimens of cephalopods were found. Four of them are deformed undeterminable orthocones, other represent nektonic Plagiostomoceras? sp., one is a slightly deformed cosmopolitan (Llandovery-Ludlow) nektobenthic pseudoorthocerid Kionoceras sp., and one is an annulated nektobenthic pseudoorthocerid orthocone Pseudocycloceras sp. or "Dawsonoceras" sp. No rugose corals are present, and tabulates were represented by only a few small favositid coral heads. It is also interesting to note that no echinoderm debris (i.e. crinoids columnals) was observed. 
Table 1. The Goniophora thula-Mytilarca boucoti Community from the Silurian, Southeast Alaska. $\mathrm{R}+\mathrm{L}-$ right and left valves (disarticulated), A - shells with conjoined valves, RA - percentage relative abundance, AA - percentage relative abundance of shells with conjoined valves, R - rank abundance.

\begin{tabular}{|c|c|c|c|c|c|c|}
\hline Species & Life habits & $\mathrm{R}+\mathrm{L}$ & A & RA & AA & $\mathrm{R}$ \\
\hline Goniophora thula & semi-infaunal & 92 & 1 & 63.1 & 2.1 & 1 \\
\hline Mytilarca boucoti & semi-infaunal & 26 & & 17.5 & & 2 \\
\hline Sanguinolites sp. & infaunal & 7 & & 4.7 & & 3 \\
\hline ?Schizodus sp. A & infaunal & 5 & & 3.4 & & 4 \\
\hline ?Colpomya aff. audae & semi-infaunal & 3 & & 2.0 & & 5 \\
\hline ?Colpomya aff. hugini & semi-infaunal & 3 & & 2.0 & & 5 \\
\hline ?Schizodus sp. B & infaunal & 3 & & 2.0 & & 5 \\
\hline Modiolopsis aff. modiolaris & semi-infaunal & 1 & & 0.7 & & 6 \\
\hline ?Modiomorpha sp. & semi-infaunal & 1 & & 0.7 & & 6 \\
\hline Bivalvia indet. & & 6 & & 4.0 & & \\
\hline Totals & & 147 & 2 & $100.1 \%$ & & \\
\hline
\end{tabular}

Age. - The dominant Goniophora thula sp. nov. is related to species described from the late Wenlock and Ludlow of Gotland (Goniophora onyx Liljedahl, 1984, Goniophora bragei Liljedahl, 1994, Goniophora brimeri Liljedahl, 1994, and Goniophora tyri Liljedahl, 1994). Goniophora thula is also closely related to the species described from the early Ludlow of the Prague Basin, Bohemia (Goniophora ascia Křǐž, 2008 and Goniophora tyri Liljedahl, 1994). Characteristic for all these species is a prominent carina composed of segments (Kř́ž 2008). Mytilarca boucoti sp. nov. is most closely related to the Late Ordovician, latest Hirnantian $M y$ tilarca mareki Kříž \& Steinová, 2009 from the Prague Basin, Bohemia. The Alaskan species has a fixed number of lateral teeth (2) while the Hirnantian species has a variable number of the lateral teeth (1-3). Representatives of Colpomya Ulrich, 1893 were described earlier from the Middle Ordovician of North America. ?Colpomya hugini Liljedahl, 1994 and ?Colpomya audae Liljedahl, 1994 from Southeast Alaska are by general morphology closely related to their nominate species described by Liljedahl (1994) from the late Wenlock and Ludlow of Gotland. The absence of a preserved hinge makes it possible just to make a questionable systematic assignment. The same is true for ?Schizodus sp. A and ?Schizodus sp. B. The earliest representatives of the family Schizodidae Newell \& Boyd, 1975 are known from the late Wenlock and Ludlow of Gotland, Sweden (Silurozodus gotlandicus Liljedahl, 1992). From the late Wenlock and early Ludlow of the Prague Basin, Bohemia was described by Kř́ž (2008) Janicula potens (Barrande, 1881). The majority of the representatives are known from Devonian to Permian rocks (Newell \& LaRocque 1969). The earliest Sanguinolites McCoy, 1844 was described from the early Ludlow of the Prague Basin, Bohemia (Sanguinolites? drupa Kříž, 2008). We conclude that Bivalvia from the locality 10RB10 in Southeast Alaska indicate a Silurian age, most probably the late Wenlock or early Ludlow.
Type locality. - U.S.A., Southeast Alaska, Chichagof Island, small quarry SE of Hoonah, field locality 10RB10, Latitude $58^{\circ} 05.716^{\prime}$ N., Longitude $135^{\circ} 23.152^{\prime}$ W. Late Wenlock or early Ludlow, medium-bedded lower siltstone interval below an overlying, upper limestone interval.

Geographic distribution. - The Goniophora thula-Mytilarca boucoti Community is analogous and homologous (Boucot \& Kříž 1999) with the diversified shallow water Janicula potens Community from the early Ludlow of the Prague Basin, Bohemia, which is accompanied mainly by abundant brachiopods and gastropods from the early Ludlow of the Prague Basin Bohemia (Kříž 2008). The community is characterized by the occurrence of several species of Goniophora, and by the dominant, probably earliest schizodid Janicula. Nepiomorphian bivalves (Kříž 2007) occur rarely $(0.8 \%$ of relative abundance). The Bohemian community is assigned to the Coral-Crinoid Community Group (Havlíček \& Štorch 1990, 1999).

Analogous and homologous also is the shallow water Silurian reef Bivalvia community (15 species) described by Watkins (1997) from the late Wenlock Racine Formation of Michigan Basin, North America. In this community occurs a rare nepiomorphian bivalve Cardiola aff. gibbosa Barrande, 1881 (only $0.06 \%$ of relative abundance), Schizodus sp. nov., Mytilarca acutirostra (Hall, 1867), Goniophora quadrilatera (Hall, 1867) accompanied by species of genera Amphicoelia Hall, 1865, and Modiolopsis Hall, 1847.

Closely related Bivalvia to the Goniophora thulaMytilarca boucoti Community were also described by Liljedahl (1984, 1992, 1994) from Gotland and Scania, Sweden. Dominant species Goniophora thula of the Alaska community is very closely related to the late Wenlock Goniophora onyx Liljedahl, 1984 from Gotland. Other closely related species to those of Gotland are 
?Colpomya aff. audae Liljedahl, 1994 and Colpomya aff. hugini Liljedahl, 1994.

The nepiomorphian bivalves (Kř́ž 2007), mainly cardiolids, which are characteristic for the peri-Gondwana region (Kř́iž 1999b), occur in the Wenlock and Ludlow of the Welsh Borderland and Wales, Avalonia (Watkins 1978, 1979; Watkins \& Berry 1977), the Ludlow of Tasmania and New South Wales (Chapman 1908, Sherrard 1959), the Malvinokaffric faunas (Sánchez 1991), the Silurian of Laurentia, Wisconsin and Illinois (Watkins 1997), Maine (Kř́ž 1979, p. 73), the middle Ludfordian and the Přídolí, Silurian, Northern Devon Island, Canadian Arctic (Křǐž 1979, p. 110, and a specimen collected by T. de Freitas, unpublished), the late Wenlock and Ludlow of Baltica (Hede 1915, Liljedahl 1984), early Ludlow of Tajmyr, Siberia (Nikiforova \& Obut 1965, Kř́̌̌ \& Bogolepova 1995), the Ludlow and Lochkovian of Caucasia (Janischevskij 1918), Mugodzhar Hills in Kazachstan (Leonenok 1955), the Wenlock and Ludlow of southern Tjan-Shan (Sinicyna 1993). Cardiola aff. agna Kř́̌ž, 1979, the characteristic representative of Nepiomorphia Kříž, 2007 was found by Bruce Reed in the early Gorstian of Alaska at Jones River (Kř́ž 1979, pp. 14 and 72).

Characteristic for the southeastern Alaskan Goniophora thula-Mytilarca boucoti Community is the characteristic lack of Nepiomorphia representatives, which may be caused just by the simple fact that they were very rare in the community, as well as in the Bohemian early Ludlow Janicula potens Community and in other shallow water communities and have not been found yet.

It can be concluded that the Goniophora thula-Mytilarca boucoti Community has its closest biotic relationship with the late Wenlock and Ludlow of Gotland in Baltica but it also has close ties with late Wenlock and early Ludlow of Bohemia (Prague Basin).

Environment interpretation. - The bivalves occur in greenish-grey, medium-bedded siltstone together with abundant brachiopods, gastropods and rare cephalopods.

The Goniophora thula-Mytilarca boucoti Community is not very diverse ( 9 species of bivalves). The dominant species Goniophora thula occurs commonly as fragments of the thick parts of the shell connected with the carina. The parts of the shell, which are thinner, occur as the detritus. Only one shell ( $1.34 \%$ of relative abundance) with conjoined valves was found. Mytilarca boucoti is preserved as mostly complete single valves as well as ?Schizodus sp. A, ?Schizodus sp. B, ?Colpomya aff. audae, ?Colpomya aff. hugini, and Modiolopsis aff. modiolaris. Sanguinolites sp., and ?Modiomorpha sp. are preserved only as fragments.

In the soft bottom environment of this locality the most abundant bivalves are semi-infaunal (6 species $-85.89 \%$ ). Other determined species are infaunal (3 species 10.07\%). Goniophora onyx Liljedah, 1984 described from the late Wenlock Gotland community (with the dominant
Nuculoidea gotlandica Liljedahl, 1983) represents according to Liljedahl (1994, p. 21, fig. 24) most probably semi-infaunal lagoonal form in which the postero-dorsal part was above the sediment surface with the carina parallel with sediment surface (snowshoe effect). Liljedahl (1994, fig. 24) also interpreted Goniophora onyx as a species living in a higher energy environment very close to or just off the reef. Dominant Goniophora thula $(65.21 \%$ of relative abundance) is very closely related to the Gotland species. The preservation of Goniophora thula mostly as fragments supports the idea about the similar mode of life and environment as in the Gotland Goniophora onyx. The abundant fragments were probably transported from the reef by erosion or by gravity flows (McGowney 1989, Watkins 1997).

In the in-situ late Wenlock, Gotland community with dominant Nuculoidea gotlandica (Liljedahl 1984, 1985, 1994), the high-density nuculoid deposit-feeders lived in the shallow water fine-grained muddy substrate with trapped organic matter. The most important reason was certainly the availability of abundant micro-organisms and food particles within the sediment (Stanley 1970, Liljedahl 1991). It may be possible that the Goniophora thulaMytilarca boucoti Community occupied the shallower parts of the fore-reef slope facies with a limited food supply by surface currents and with an anorganic sediment (siltstone). Lack of deposit feeders was also described in the late Wenlock and early Ludlow Racine Formation, North America reef bivalve association by Watkins (1997). Quite rare cephalopods were nektonic and nektobenthic.

Brachiopods were studied by Arthur J. Boucot and Robert B. Blodgett and the gastropods were studied by David M. Rohr. The brachiopods are mostly represented by wholly disarticulated specimens, with the exception of a minority of the isorthid specimens which remained articulated. The high degree of disarticulation suggests a moderately high-energy setting, consistent with our interpretation of moderate transport (but not great distances) on an inclined shelf to slope transition.

\section{Conclusions}

1. Synecological synthesis must wait till the whole fauna from the field locality $10 \mathrm{RB} 10$ will be treated. The Goniophora thula-Mytilarca boucoti Community probably occupied the shallower parts of a fore-reef upper slope facies composed of siltstone sediment without organic microparticles and microorganisms. The abundant fragments of dominant Goniophora thula sp. nov. were transported by gravity flows of fore-reef sediment, probably derived immediately seaward of the cyanobacterial reef which delimited the outer edge of the Kennel Creek Limestone carbonate platform. In this upper slope environment could be found fine-grained siliciclastic sediment and carbonate 
debris shed by periodic slope failure at the carbonate shelf-slope break.

2. The Goniophora thula-Mytilarca boucoti Community is composed of species which show their closest biological ties to species described from the late Wenlock and Ludlow of Gotland, Sweden, Baltica (Liljedahl 1983, 1984, 1985, 1991, 1992 and 1994) and from the latest Ordovician, late Wenlock and early Ludlow of the Prague Basin, Bohemia, Perunica (Kř́řz 2008, Kř́ž \& Steinová 2009).

3. The latest interpretation that the Alexander terrane of Alaska (from where the Goniophora thula-Mytilarca boucoti Community was described) was rifted from the eastern margin of the Siberian palaeocontinent during late Devonian-early Carboniferous time (Blodgett et al. 2010) may not be contrary with the biological ties of the bivalves with Baltica. The Siberian palaeocontinent was during the Wenlock and early Ludlow quite close to the eastern coasts of Baltica. Recent surface currents of average velocity can transport bivalves with a pelagic larval life span of about 6 weeks in one generation for the distance of 900-1,500 km (Thorson 1961). There was no geographic barrier for the Silurian bivalves to migrate between Baltica and Siberia and then along Siberian shelf when we accept the possible existence of island arcs in the area. This explains the existence of Nepiomorphia Kř́̌ž, 2007 bivalve genera (e.g. Sibirinka Bogolepova \& Kř́žz, 1995, Cardiola Broderip in Murchison, 1939, Dualina Barrande, 1881 and Hercynella Kayser, 1878) in Siberia, peri-Gondwana, Perunica, Australia, Baltica and also in the Alaskan accreted terranes (Blodgett et al. 2002, 2010).

Almost no provincialism, but rather widest cosmopolitanism is characteristic for Silurian Bivalvia genera, which were dispersed in most of the regions of the world (Kř́ž 1999b) due to their relatively long pelagic larval life and the relatively small distances between the basins, islands and continents on the Silurian Globe (e.g. Cocks \& Scotese 1991). Limiting physical factors like temperature, salinity, substrate, food, oxygen content, light and depth were very critical for the Bivalvia distribution during the Silurian.

\section{Acknowledgements}

We are indebted to Arthur J. Boucot, Department of Zoology and Geology, Oregon State University, Corvallis, Oregon, U.S.A. for valuable suggestions and linguistic improvement, to John Pojeta, Jr., U.S. Geological Survey, Washington, D.C., U.S.A. for his help with American literature. We also thank to Štěpán Manda, Czech Geological Survey, Prague, Czech Republic for his part on the cephalopods and for his assistance with manuscript editing and digitalization of the draft figures. A deep heartfelt expression of gratitude is also extended to Jeff Skaflestad of Hoonah, Alaska, who provided excellent guidance during our field work on
Chichagof Island and led us to the quarry where the fauna described here was discovered. The research was partly funded by GA ČR (Czech Science Foundation) project 205/09/0703.

\section{References}

BARRANDE, J. 1881. Systême silurien du centre de la Bohême. Classe des Mollusques, ordre des Acéphalés 6. 342 pp, 356 pls. Prague \& Paris.

BerG, H.C., Jones, D.L. \& Richter, D.H. 1972. Gravina-Nutzotin Belt; tectonic significance of an upper Mesozoic sedimentary and volcanic sequence in southern and southeastern Alaska. U.S. Geological Survey Professional Paper 800-D, D1-D24.

BiLlings, E. 1874. (MS not published) On some of the fossils of the Arisaig Series of rocks. Paleozoic Fossils, Geological Survey Canada 2(1), 1-144.

Blodgett, R.B., Boucot, A.J., Rohr, D.M. \& Pedder, A.E.H. 2010. The Alexander terrane of Alaska - a displaced fragment of Northeast Russia? Evidence from Silurian-Middle Devonian megafossils and stratigraphy. Memoirs of the Association of Australasian Palaeontologists 39, 323-339.

Blodgett, R.B., Rohr, D.M. \& Boucot, A.J. 2002. Paleozoic links among some Alaskan accreted terranes and Siberia based on megafossils, 273-290. In Miller, E.L., Grantz, A. \& KLEMPERER, S.L. (eds) Tectonic evolution of the Bering Shelf-Chukchi Sea-Arctic margin and adjacent landmasses. Geological Society of America Special Paper 360.

Blodgett, R.B., Rohr, D.M., KarL, S.M. \& Baichtal, J.F. 2003. Early Middle Devonian (Eifelian) gastropods from the Wadleigh Limestone in the Alexander terrane of southeastern Alaska demonstrate biogeographic affinities with central Alaskan terranes (Farewell and Livengood) and Eurasia, 105-115. In GallowAY, J.P. (ed.) Studies in Alaska by the U.S. Geological Survey, 2001. U.S. Geological Survey Professional Paper 1678.

Bogolepova, O.K. \& KŘ́ǐž, J. 1995. Ancestral forms of Bohemian type Bivalvia from the lower Silurian of Siberia (Tungusskaja Syneclise, Russia). Geobios 28(6), 691-699. DOI 10.1016/S0016-6995(95)80062-X

Boucot, A.J. \& KŘíž, J. 1999. Definition of the terms "homologous" and "analogous" community. In Boucot, A.J. \& LAWSON, J.D. (eds) Paleocommunities: a case study from the Silurian and Lower Devonian. World and Regional Geology Series 11, 32. xv +895 pp. Cambridge University Press, Cambridge.

Chapman, F. 1908. A monograph of the Silurian bivalved Mollusca of Victoria. Memoirs of the National Museum, Melbourne 1908(2), 5-62.

Clough, J.G. \& BlodgetT, R.B. 1988. Silurian-Devonian algal reef mound complex of southwest Alaska, 246-250. In GeLDSETZER, H. \& JAmes, N.P. (eds) Reefs, Canadian and adjacent areas. Canadian Society of Petroleum Geologists Memoir 13.

Cocks, L.R.M. \& SCOTESE, C.R. 1991. The global biogeography of the Silurian Period, 109-122. In Bassett, M.G., LANE, P.D. \& Edwards, D. (eds) The Murchison Symposium: proceedings of an international conference on The Silurian System. Special Papers in Palaeontology 44, 1-397.

ConRAD, T.A. 1838. Report on the palaeontological department of the survey (of New York). New York Geological Survey Annual Report 2, 107-119. 
ConRad, T.A. 1842. Observations on the Silurian and Devonian systems of the United States, with descriptions of new organic remains. Journal of the Academy of Natural Science of Philadelphia 8(2), 228-280.

FisCHER, P. 1880-87. Manuel de conchyliologie et de paléontologie conchyliologique ou histoire naturelle des mollusques vivants et fossiles. 1880, pp. 1-112; 1881, pp. 113-304; 1882, pp. 305-416; 1883, pp. 417-608; 1884, pp. 609-688; 1885, pp. 689-896; 1886, pp. 897-1008; 1887, pp. 1009-1369. F. Savy, Paris.

Hall, J. 1847. Natural History of New York. Paleontology. Vol. 1. 338 pp., 88 pls. Geological Survey of New York, New York.

Hall, J. 1865. Account of some new or little known species of fossils from rocks of the age of the Niagara group. $18^{\text {th }}$ Annual Report of New York State Cabinet, 48 pp (printed in advance).

HaLl, J. 1867. Descriptions of some new fossils from the Niagara Group. New York State Cabinet of Natural History, $20^{\text {th }} \mathrm{An}$ nual Report, 308-401.

HaLl, J. 1883. Lamellibranchiata plates and explanations. Natural History of New York, Paleontology 5(1), 1-20, pls 1-34, 36-41, 43-80.

HALL, J. 1884. Lamellibranchiata I, descriptions and figures of the Monomyaria of the Upper Helderberg, Hamilton, and Chemung groups. Natural History of New York, Geological Survey of New York, Paleontology 5(1), 1-268, pls 1-33, 81-92.

HALL, J. 1885. Lamellibranchiata 2, descriptions and figures of the Dimyaria of the Upper Helderberg, Hamilton, Portage, and Chemung Groups. Natural History of New York, Geological Survey of New York, Palaeontology 5(1), 1-540, pls 34-80, 93-96.

Hall, J. \& Whitfield, R.P. 1869. Preliminary notice of the lamellibranchiate shells of the Upper Helderberg, Hamilton and Chemung groups, with others from the Waverly sandstones, Part 2, $80 \mathrm{pp}$.

HAVlíčEK, V. \& ŠTORCH, P. 1990. Silurian brachiopods and benthic communities in the Prague Basin (Czechoslovakia). Rozpravy Ústředního ústavu geologického 48, 1-275.

HaVlíčEK, V. \& ŠTORCH, P. 1999. Silurian and Lochkovian communities in the Prague basin (Barrandian area, Czech Republic), 200-228. In Boucot, A.J. \& Lawson, J.D. (eds) Final report, project Ecostratigraphy. Paleocommunities: A case study from the Silurian and Lower Devonian. 895 pp. Cambridge University Press, Cambridge.

HedE, J.E. 1915. Skånes Colonusskiffer. Lunds Universitets årsskrift, N.F. 2, 11(6), 1-65.

IsBerg, O. 1934. Studien über Lamellibranchiata des Leptaenakalkes id Dalarna. 493 pp. Håkan Ohlssons, Lund.

JANISCHEVSKIJ, M. 1918. On some representatives of the Upper Silurian fauna of the Caucasus. Annuaire de la Société Paléontologique de Russie 1917, 2(3), 47-64.

Jones, D.L., Irwin, W.P. \& Ovenshine, A.T. 1972. Southeast Alaska; a displaced continental fragment? U.S. Geological Survey Professional Paper 800-B, B211-B217.

KARL, S.M. 1999. Preliminary geologic map of northeast Chichagof Island, Alaska. U.S. Geological Survey Open-File Report 96-53, 12 pp., 1 map sheet, scale $1: 63,360$.

KAYSER, E. 1878. Die Fauna der ältesten Devon-Ablagerungen des Harzes. Text und Atlas. Abhandlungen zur geologischen
Spezialkarte von Preussen und den Thüringischen Staaten 2(4), 23I, 1-295, 36 pls.

KIRK, E. 1927a. Pycnodesma, a new molluscan genus from the Silurian of Alaska: Proceedings of the United States National Museum 71(20), 1-9.

KIRK, E. 1927b. Pycinodesma, a new name for Pycnodesma Kirk not Schrammen. Journal of the Washington Academy of Sciences 17, 543.

Kirk, E. \& AMsden, T.W. 1952. Upper Silurian brachiopods from southeastern Alaska. U.S. Geological Survey Professional Paper 233(C), 53-66.

KŘiž, J. 1979. Silurian Cardiolidae (Bivalvia). Sborník geologických věd, Palaeontologie 22, 1-160.

Kর̌iž, J. 1999a. Bivalvia dominated communities of Bohemian type from the Silurian and Lower Devonian carbonate facies, 229-252. In Boucot, A.J. \& Lawson, J.D. (eds) Final report, project Ecostratigraphy. Paleocommunities: A case study from the Silurian and Lower Devonian. 895 pp. Cambridge University Press, Cambridge.

Ǩ̌iž, J. 1999b. Silurian Bivalvia - Evolution, palaeoecology, palaeogeography, importance for biostratigraphy and correlation. Abhandlungen der Geologischen Bundesanstalt 54, 377-384.

KŘiž, J. 2007. Origin, evolution and classification of the new superorder Nepiomorphia (Mollusca, Bivalvia, Lower Palaeozoic). Palaeontology 50(6), 1341-1365.

KŘíž, J. 2008. A new bivalve community from the lower Ludlow of the Prague Basin (Perunica, Bohemia). Bulletin of Geosciences 83(3), 237-280.

Kর̌iž, J. \& Bogolepova, O.K. 1995. Cardiola signata Community (Bivalvia) in cephalopod limestones from Tajmyr (Gorstian, Silurian, Russia). Geobios 28(5), 573-583.

KŘiž, J. \& STeinovÁ, M. 2009. Uppermost Ordovician bivalves from the Prague Basin (Hirnantian, Perunica, Bohemia). Bulletin of Geosciences 84(3), 409-436.

LAMARCK, J.B.P.A. DE M. DE 1819. Histoire Naturelle des Animaux sans Vertèbres 6, Part 1. 232 pp. Paris.

Lathram, E.H., Loney, R.A. \& Condon, W.H. 1958. Progress map of the geology of the Juneau quadrangle, Alaska. U.S. Geological Survey Miscellaneous Investigations 276, 1 sheet, scale $1: 250,000$.

Lathram, E.H., Loney, R.A., Condon, W.H. \& Berg, H.C. 1959. Progress map of the geology of the Juneau quadrangle, Alaska. U.S. Geological Survey Miscellaneous Investigations Map I-303, 1 sheet, scale $1: 250,000$.

LEONENOK, N.I. 1955. Siluriyskiye otlozheniya Kos-Istekskogo rayona (Severnye Mugodzhary). Trudy Laboratorii Uglya Akademii Nauk SSSR 3, 116-225.

LiLjedAHL, L. 1983. Two silicified bivalves from Gotland. Sveriges Geologiska Undersökning, Serie C 799, 77(1), $1-51$.

LiLjEDAHL, L. 1984. Silurian silicified bivalves from Gotland. Sveriges Geologiska Undersökning, Serie C 804, 78(2), 1-82.

LILJEDAHL, L. 1985. Ecological aspects of a silicified bivalve fauna from the Silurian of Gotland. Lethaia 18(1), 53-66. DOI 10.1111/j.1502-3931.1985.tb00684.x

LiLJEDAHL, L. 1991. Contrasting feeding strategies in bivalves from the Silurian of Gotland. Palaeontology 34(1), 219-235.

LiLJEDAHL, L. 1992. Silurozodus, new genus, the oldest known 
member of the Trigonioida (Bivalvia, Mollusca). Paläontologische Zeitschrift 66(1/2), 51-65.

LILJEDAHL, L. 1994. Silurian nuculoid and modomorphid bivalves from Sweden. Fossils and Strata 33, 1-89.

LinNÉ, C. 1758. Systema naturae per regna tria naturae, secundum classes, ordines, genera, species, cum characteribus, differentiis, synonymis, locis. Edit Decima, reformata. 824 pp. Holmiae.

Loney, R.A., Berg, H.C., Pomeroy, J.S. \& Brew, D.A. 1963 a. Reconnaissance geologic map of Chichagof Island and northwestern Baranof Island, Alaska. U.S. Geological Survey Miscellaneous Geologic Investigations Map I-388, 7 pp., 1 sheet, scale $1: 250,000$.

Loney, R.A., Condon, W.H. \& Dutro, J.T., Jr. 1963b. Geology of the Freshwater Bay area, Chichagof Island, Alaska. U.S. Geological Survey Bulletin 1108-C, C1-C54, 2 sheets, scale $1: 63,360$

McCoy, F. 1844. A synopsis of the characters of the Carboniferous Limestone fossils of Ireland. 274 pp. Privately printed, re-issued 1862, Williams \& Norgate, London.

McGovney, J.E. 1989. Thornton reef, Silurian, northeastern Illinois. Canadian Society of Petroleum Geologists Memoir 13, 330-338.

MCLEarn, F.H. 1924. Palaeontology of the Silurian rocks of Arisaig, Nova Scotia. Memoir. Geological Survey of Canada 175(118), 1-179.

Miller, S.A. 1877. The American Palaeozoic fossils, a catalogue of the genera and species. 253 pp. Published by author, Cincinnati.

MurChISON, R.I. 1839. The Silurian System founded on geological researches in the counties of Salop, Hereford, Radnor, Montgomery, Caermarthen, Brecon, Pembroke, Monmouth, Gloucester, Worcester and Stafford; with descriptions of the coalfields and overlying formations. i-xxxii, $768 \mathrm{pp.} \mathrm{John}$ Murray, London.

Newell, N.D. \& LaRocQue, A. 1969. Family Grammysiidae S.A. Miller, 1877, N819-N823. In Moore, R.C. (ed.) Treatise on invertebrate paleontology, Part N, Mollusca 6. Bivalvia. 951 pp. Geological Society of America \& University of Kansas Press, Boulder \& Lawrence.

Newell, N.D. \& Boyd, D.W. 1975. Parallel evolution in early trigoniacean bivalves. Bulletin of the American Museum of Natural History 154(2), 55-162.

Nikiforova, O.I. \& OBut, A.M. 1965. Siluriyskaya sistema. 529 pp. Nedra, Moscow.

PedDER, A.E.H. 2006. Zoogeographic data from studies of Paleozoic corals of the Alexander terrane, southeastern Alaska and British Columbia, 29-57. In HaGgart, J.W., Enkin, R.J. \& Monger, J.W.H. (eds) Paleogeography of the North American cordillera: Evidence for and against large-scale displacements. Geological Association of Canada, Special Paper 46.

Phillips, J. 1848. The Malvern hills, compared with the Palaeozoic districts of Abberley, Woolhope, May Hill, Tortworth, and Usk. Memoirs of the Geological Survey of Great Britain 2(2), 1-330.

PojeTA, J. JR. 1971. Review of Ordovician Pelecypods. U.S. Geological Survey Professional Paper 695, 1-46.

Pojeta, J. \& Gilbert-Tomlinson, J. 1977. Australian Ordovician pelecypod molluscs. Department of National Resources, Bu- reau of Mineral Resources, Geology and Geophysics Bulletin 174, 1-64.

Pojeta, J., JR., Zhang, R. \& YAng, Z. 1986. Systematic palaontology of the Devonian pelecypods of Guangxi and Michigan, 57-102. In PoJETA, J., JR. (ed.) Devonian rocks and Lower and Middle Devonian pelecypods of Guangxi, China, and the Traverse Group of Michigan. U.S. Geological Survey Professional Paper 1394-A-G.

Rigby, J.K., Nitecki, M.H., Soja, C.M. \& Blodgett, R.B. 1994. Silurian aphrosalpingid sphinctozoans from Alaska and Russia. Acta Palaeontologica Polonica 3, 341-391.

Rohr, D.M., Blodgett, R.B., Boucot, A.J. \& Skaflestad, J. 2011. Upper Silurian facies and fauna of northeast Chichagof Island, Southeast Alaska [abstract]. 2011 Western Region Meeting SPE Pacific Section, AAPG 6-14 May 2011. Program with Abstract, p. 82.

SANCHEZ, T.M. 1991. El genero Dualina (Bivalvia, Praecardioida) en formacion Lipeon (Silurico), Sierra de Zapla, Provincia de Jujuy, Argentina. Ameghiniana 28(1-2), 31-34.

SherRARD, K. 1959. Some Silurian lamellibranchs from New South Wales. Proceedings of the Linnean Society of New South Wales 84(3), 356-372.

SinicynA, I.N. 1964. Representatives of the Modiolopsidae Fischer from the Silurian sediments of Podolia. Vestnik Leningradskogo universiteta 24, 44-50. [in Russian]

SinicynA, I.N. 1993. Klass Bivalvia - dvustvorchatyye mollyuski, 10-27. In Kiselev, G.N. (ed.) Atlas mollyuskov i brachiopod silura i devona yuzhnogo Tyan-Shanya. Izdatelstvo Sankt-Petersburgskogo Universiteta, St. Petersburg.

Sowerby, J. 1921. Manual of conchology, Vol. 4. 12 pp. I. Sowerby, London.

StAnLEY, S.M. 1970. Relation of shell form to life habits in the Bivalvia (Mollusca). Memoir of the Geological Society of America 125, 1-296.

Thorson, G. 1961. Length of pelagic larval life in marine bottom invertebrates as related to larval transport by ocean currents, 455-474. In Sears, M. (ed.) Oceanography. American Association for the Advancement of Science, Freeman and Company, Washington.

ULRICH, E.O. 1893. New and little known Lamellibranchiata from the Lower Silurian rocks of Ohio and adjacent states. Ohio Geological Survey Report 7(2), 627-693.

Verneuil, P.E.P. DE \& Murchison, R.I. 1844. Note sur les équivalents du système permien en Europe, suivie d'un coup d'oeil general sur l'ensemble de ses fossiles, et d'un tableau des espèces. Bulletin de la Société Géologique de France, série 2, $1,475-517$.

WAtKIns, R. 1978. Bivalve ecology in a Silurian shelf environment. Lethaia 11(1), 41-56. DOI 10.1111/j.1502-3931.1978.tb01215.x

WAtKINS, R. 1979. Benthic community organization in the Ludlow Series of the Welsh Borderland. Bulletin of the British Museum (Natural History), Geology 31(3), 175-280.

WAtKIns, R. 1997. Paleoecology of Silurian reef bivalves, Racine Formation, North America. Lethaia 29(2), 171-180. DOI 10.1111/j.1502-3931.1996.tb01873.x

WATKINS, R. \& BERRY, W.B.N. 1977. Ecology of a late Silurian fauna of graptolites and associated organisms. Lethaia 10(4), 267-286. DOI 10.1111/j.1502-3931.1977.tb00622.x 
